
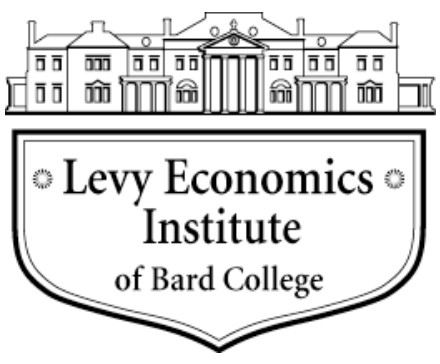

Working Paper No. 820

\title{
Minsky, Monetary Policy and Mint Street: Challenges for the Art of Monetary Policymaking in Emerging Economies*
}

by

\author{
Srinivas Yanamandra \\ Manchester Business School
}

November 2014

\begin{abstract}
* Views expressed in the paper are personal and do not necessarily represent the views of the organization that the author represents. While data/references have been obtained from various sources, any omissions/errors are the responsibility of the author alone.

* Deputy General Manager, Compliance Group, ICICI Bank, India. Contact: dryanamandra@gmail.com. Tel.: 00912226537637 or 00919821509192 (mobile).
\end{abstract}

The Levy Economics Institute Working Paper Collection presents research in progress by Levy Institute scholars and conference participants. The purpose of the series is to disseminate ideas to and elicit comments from academics and professionals.

Levy Economics Institute of Bard College, founded in 1986, is a nonprofit, nonpartisan, independently funded research organization devoted to public service. Through scholarship and economic research it generates viable, effective public policy responses to important economic problems that profoundly affect the quality of life in the United States and abroad.

Levy Economics Institute

P.O. Box 5000

Annandale-on-Hudson, NY 12504-5000

http://www.levyinstitute.org

Copyright (C) Levy Economics Institute 2014 All rights reserved 


\begin{abstract}
This paper examines the emerging challenges to the art of monetary policymaking using the case study of the Reserve Bank of India (RBI) in light of developments in the Indian economy during the last decade (2003-04 to 2013-14). The paper uses Hyman P. Minsky’s financial instability hypothesis as the conceptual framework for evaluating the endogenous nature of financial instability and its potential impact on monetary policymaking, and addresses the need to pursue regulatory policy as a tool that is complementary to monetary policy in light of the agenda of reforms put forward by Minsky. It further reviews the extensions to the Minskyan hypothesis in the areas of setting fiscal policy, managing cross-border capital flows, and developing financial institutional infrastructure. The lessons learned from the interplay of policy choices in these areas and their impact on monetary policymaking at the RBI are presented.
\end{abstract}

Keywords: Financial Crisis; Central Bank; Monetary Policy; Bank Regulation; Fiscal Policy; Exchange Rate Policy; Financial Institution Infrastructure

JEL Classifications: E58, G01, G28 


\section{INTRODUCTION}

The art of monetary policy-making by central banks has been subjected to rigorous research in the aftermath of the recent global financial crisis. Various dimensions of monetary policymaking - its objectives, tools for operationalizing the same and the complexities arising from global macro-economic environment-have received wide academic attention in recent times. The research focuses largely on incorporating learnings from the recent global financial crisis into the day-to-day functioning of central banks around the world.

Against the backdrop descrived above, the experience of the Reserve Bank of India (RBI —having its head office on Mint Street in Mumbai, India) during the previous decade (2003-04 to 2013-14) offers interesting perspectives in the area of monetary policy making. At the time of the global financial crisis, RBI was credited as one of the few central banks in the world that insulated the country's domestic banking system from the impact of the global financial crisis. However, following the financial crisis, the RBI experienced challenges in the pursuit of monetary policy-making arising from the impact of global macro-economic developments, structural issues in domestic economy, and volatility in domestic exchange rates.

This paper therefore uses the experience of the RBI as a case study to outline the challenges to the art of monetary policy-making in emerging economies. This paper uses Hyman P. Minsky's Financial Instability Hypothesis as the conceptual framework for evaluating the endogenous nature of financial instability and the limitations of monetary policy in containing the same. This paper addresses the need to pursue appropriate regulatory policy as a tool that is complementary to the monetary policy in light of the agenda of reforms put forward by Minsky. This paper further reviews the extensions to Minskian hypothesis in the areas of fiscal policy management, managing cross-border capital flows, and development of financial institutional infrastructure. The learnings arising from inter-play of policy choices in these areas and their impact on monetary policy-making at the RBI are presented in the paper. 


\section{LITERATURE REVIEW-MINSKY AND MONETARY POLICY}

Minsky demonstrated, using the Financial Instability Hypothesis, how banks and other financial institutions could, as they became increasingly complex and interdependent, bring the entire economic system crashing down. Writings on Minsky (Wray 2007, Roubini 2010, Keen 2011) indicate that the Minskian analysis is in turn built on insights of great non-neoclassical thinkers like Schumpeter, Fisher, and Keynes. However, Minsky’s strength, as Keen (2011, p.326) points out, was to weave these "individually powerful and cohesive but incomplete analysis into one coherent tapestry that explained the occasional depressions the capitalist economy is inherently exposed to."

This section therefore begins with an overview of the Financial Instability Hypothesis, including the role of bank finance in exacerbating financial instability. It thereafter outlines the limitations of monetary policy in achieving financial stability and highlights the agenda of regulatory reforms as suggested by Minsky. Finally, this section concludes with three important theoretical extensions to the Minskian hypothesis resulting in additional challenges to the pursuit of monetary policy by central banks.

\section{a) Financial Instability Hypothesis-An Overview}

Prior to the global financial crisis in 2007-08, monetary policy-making by central banks was dominated by mainstream economics that relied on theories such as the efficient market hypothesis. The dominant thinking in academic and policy-making circles at that time therefore was that while external adverse shocks can push markets away from their natural optimal state, markets that are by definition equilibrium-seeking systems will attain a steady course on their own without external influence (Cooper 2010). Therefore, there cannot be any internal destabilizing force in the market, nor is any external intervention required to restore market equilibrium in case of exceptional situations (Bezemer 2009). Central banks that believed in these theories developed their policy actions with the overarching philosophy that they really should not be in the business of figuring out when asset prices are too high; after all, they do not really know much more than market participants (Allen and Gale 2007, Borio 2003, Roubini 2010). Further, as markets naturally achieve an optimal equilibrium, central banks supporting the efficient market hypothesis also believed that any interference with market forces can at best achieve nothing, but will more likely push the system away from equilibrium towards a sub- 
optimal state (Rajan 2010). As Roubini (2010, p. 4) points out, academic community and regulators that believed in these principles therefore considered that financial crises are "freak events: highly improbable, extremely unusual, largely unpredictable and fleeting in their consequences."

If markets are believed to be fundamentally stable as per the mainstream efficient market hypothesis, "can IT - a spectacular collapse such as the Great Economic Depression of 1929 happen again?" This was the question Minsky focused upon through his various essays on instability and finance. To answer this question, mainstream economic theory prior to the crisis, dominated by monetary theorists (and in particular those led by Friedman and Schwartz (1963)) argued that the great economic depression of 1929 was a classic case of central banks failing to take quick and decisive action and it was not fundamental failure of stability of markets. The monetary theorists claimed that the failure of central banks to resort to timely monetary policy easing during 1929, when they anticipated recession, resulted in falling levels of aggregate demand in the economy. A free market economy without excessive regulatory intervention was therefore still considered a valid premise if the central bank could swiftly handle the recessionary situations by keeping the financial system from imploding, and restoring the market, through effective monetary policy action (Moore 1979, Kydland and Prescott 1990, Krugman and Eggertsson 2012). Rajan (2010, p.101) argued that, based on these theories, central bankers have become "triumphant" even in making public statements that the policy levers for managing a modern economy were well understood by them. Policy makers have therefore showcased periods of milder recessions in the pre-crisis period as a testimony of their achievements (Greenspan 1997, Bernanke 2004).

However, in order to answer the question as to whether the great depression can happen again, Minsky believed that it is necessary to call for an alternative economic theory that makes great depressions as one of the possible states within which the real world capitalist economy can find itself. Minsky (1984, p. 16) argued that, "if a theory is to explain an event, the event must be possible within the theory. Furthermore, if a theory is to guide policy that aims at controlling or preventing an event, the event must be possible within the theory." According to Minsky, when judged against this standard, extant mainstream economic theory based on the efficient market hypothesis suffers from serious limitations. In particular, the extant theory concludes that crises are extremely rare events, which can occur only because of policy errors or from non-essential institutional flaws. 
Minsky rejected mainstream economics as irrelevant in analysing a real-world capitalist economy and instead argued that "stability is destabilising" (Papadimitriou and Wray 2008 p. xii). Minsky, according to them, believed that relative tranquility gradually encourages more risk-taking and innovative behavior, while disrupting the conditions that generate coherence and tranquility. That is, the market forces that operate when a system is stable will push it toward instability, so that even if anything like equilibrium could be achieved, it would be offset by behavioral responses that would quickly move the economy away from equilibrium. This difference in Minsky's treatment of capitalist economy had two different academic implications. First, unlike other critical analyses of capitalist processes, which emphasize the crash, Minsky was more concerned with the behavior of corporate agents and financial institutions during the euphoric periods. Second, unlike other analyses that blame "shocks," "irrational exuberance," or "foolish" policy, Minsky argued that the processes that generate financial fragility are "natural" or "endogenous" to the system (Papadimitriou and Wray 2008, p. xii).

\section{b) Bank Finance, Financial Instability and Limitations of Monetary Policy}

Minsky stated that, the "overall fragility-robustness of the financial structure, upon which the cyclical stability of the economy depends, emerges out of loans made by bankers" (Minsky 2008 [1986], p. 261). Minsky explained the endogenous process by stating that operating units in an economy are primarily dependent upon the immediate credit extended by banks to finance the investment in capital assets that can generate cash flows in the future. He provided insights into the borrowing behavior of these operating units by separating them into three types of borrowers - hedge borrowers (whose source of repayment of debt in its entirety is operating income), speculative borrowers (who use operating income for repayment of interest but rely on new loans for repayment of the principal) and Ponzi borrowers (whose operating income is not sufficient to even repay the interest obligation). Minsky stated that the borrowing units create increased demand for bank finance over a period of time, which creates disequilibrating pressures in the economy. The more the demand for investment finance by operating units, the more the profit-seeking bankers will find ways of accommodating their customers and as a result, the "supply of financing from banks grows so fast that prices of capital assets, prices of investment output, and finally, prices of consumption output all rise" (Minsky 2008 [1986], p. 264). Bank finance thus sets the stage for financing an inflationary expansion by unleashing the "animal spirits" of the operating units. The way to deal with inflationary growth through 
expansion of credit by banks is to curtail the supply of bank finance through monetary policy tools available at the disposal of central banks.

Minsky (1984) therefore examined the efficacy of two traditional monetary policy tools of central banks - manipulation of reserve requirements and increasing interest rates - for curtailing the supply of money in the system. Minsky explains that reserve-ratio manipulation as a central bank tool assumes the operation of the money-multiplier theory, which postulates a decrease in money supply by banks through an increase in deposit reserve requirements by a central bank. However, as Holmes (1969) argues, the money multiplier model theoretically assumes that the banking system expands only after the central bank puts reserves in the banking system, but in the real world, banks extend credit, creating deposits in the process, and look for reserves later. Overtveldt (2010) also argues that the money-multiplier model is practically difficult to operate, as profit-seeking bankers tend to always look for alternative funding sources that are not subject to reserve requirements. In the process, banks endeavor to give ever greater promises of safety to alternative fund providers either by shortening the term of liabilities or by providing special assurances. This results in the creation of new funding sources by banks through innovative financial instruments. Minsky, therefore, argued that normal profit seeking by banks through innovation continually subverts the attempts by authorities to constrain money-supply growth through deposit reserves (Minsky 1984).

Minsky examined the other central banking tool—increase in interest rates - for controlling the money supply, which forces banks to tighten financing terms (by increasing the rate of interest or demanding better collateral). The supply price of investment finance therefore exceeds the demand price and a period of credit contraction sets in. During this phase, some of the firms involved in "hedge finance" are shunted to the "speculative finance" group and those involved in the speculative finance group become "Ponzi borrowers." As borrowers are shunted to the next level, panic sets in in the market as borrowers fear a mounting debt burden. This results in sudden contraction of credit and distress sales for repayment of bank finance, leading to falling asset prices and debt deflation, and eventually crisis sets in (Kindleberger and Aliber 2005). Thus the central bank could indirectly trigger a crisis if it resorts to an increase in the interest rate to curtail money supply growth.

By examining these alternatives, Minsky argued that it is evident that controlling the money supply in order to stabilize the economy, from the inherent destabilizing forces leading to inflationary growth, is not sufficient. In his view, this will either be ineffective (if central 
banks pursue a manipulation of reserve ratios) or result in a dismal cycle that brings about debt deflation (if central banks pursue a manipulation of interest rates).

The aforementioned paragraphs deal with ineffectiveness of monetary policy in an expansionary phase to curtail excessive growth through bank finance in an economy. Cooper (2005, 2010), however, explained the Minskian hypothesis as to why monetary policy will be ineffective during recessionary periods for stimulating the growth. Cooper (2005) argued that the use of a monetary policy tool (by lowering interest rates) for reviving economic growth by central banks during recession acts as an "indiscriminate-asymmetric stimulus" characterised by a low-interest rate regime for an indefinitely long period of time. The continued success of such a policy provokes central banks to pursue monetary tweakening over a period of time not necessarily when growth was actually weakened but even before when it was "anticipated" to be weakened. Such an action will be considered asymmetric when the low-interest rate stimulus is used when economic growth is weak while doing nothing to subsequently counter strong growth for a relatively long period of time. Cooper (2005) argued that such a monetary policy stance encourages the economy to behave like an unstable positive feedback system (in which a change to the system produces conditions that increase the magnitude of that change), thereby promoting destabilizing tendencies in the economy.

Therefore, to conclude in the words of Minsky, "if we are to bring a halt to the dismal cycle, far-reaching structural reforms are needed" in the capitalist financial system (Minsky 1984, p. 200).

\section{c) Regulation as a Supplementary Tool to Monetary Policy}

Without subjecting his recommendations to mathematical rigour, Minsky stressed that "periodic reforms of the banking system are needed to prevent the development of a financially unstable economy that cannot readily be contained” (Minsky 2008 [1986], p. 355). Minsky, however, criticized the mainstream monetary economic theory that postulates that central banks should focus on money supply and operate to achieve a constant rate of growth. According to Minsky, this view results in central banks excessively concentrating on monetary policy management by wearing policy blinders that restrict their vision, so that they tend to ignore financing relations by which monetary phenomena affect economic activity. Minsky, however, argued that instead of seeking to control the economy through the monetary policy route, central banks should focus on their functions as regulators and supervisors of the financial system and as lenders of last 
resort. By carefully monitoring and regulating the financial system, Minsky opined that central banks can hinder the endogenous tendency towards financial fragility (De Antoni 2007).

Minsky's agenda for regulatory reforms, which he termed as having an anti-aaissez-faire theme, therefore emphasise that "in a world where the internal dynamics imply instability, a semblance of stability can be achieved or sustained by introducing conventions, constraints and interventions into the environment" by central banks (Ferri and Minsky 1991, p. 21). Minsky criticized that the mainstream economic theory leads to the conclusion that regulatory arrangements reflect superstition and ignorance. He stated that this conclusion was arrived at because the mainstream theory assumes that the financial instability phenomena, which central bank regulations and discretionary power are designed to deal with, do not exist in nature. However, according to Minsky, regulatory powers need to be exercized by central banks in a manner that they should be able to "steer the evolution of financial structure" (Minsky 2008 [1986], p. 359).

Minsky (2008 [1986], p. 356) further argued that "banks are complex profit-seeking organizations that have a multitude of actual and potential types of liabilities and that innovate in response to profit opportunities." In their attempt to increase the spread between asset and liability interest rates, banks tend to improve the products and services they provide to borrowers and depositors by creating new types of paper. Thus Minsky observed that new financial innovations result from profit opportunities, and underscored that central banks, through regulatory tools, should favor stability enhancing and discourage instability augmenting innovative practices. Minsky's agenda for reforms therefore further called for the exercise of regulations by central banks in a manner that they promote financial innovation conducive to successful capitalism (Tymoigne 2009, Vercelli 2009).

Minsky's agenda for financial sector reforms thus calls a for larger role of financial regulation in central bank functioning. To sum up in Minsky's words:

"To contain the evils that market systems can inflict, capitalist economies developed sets of institutions and authorities, which can be characterized as the equivalent of circuit breakers. These institutions in effect stop the economic processes that breed incoherence and restart the economy with new initial conditions" (Minsky et al 1994, p. 6).

\section{d) Extensions to Financial Instability Hypothesis}

The discussion of the Financial Instability Hypothesis in the preceding section outlines the limitations of traditional monetary policy tools of central banks and advocates appropriate use of 
regulatory mechanisms as supplementary tools to monetary policy, for achieving financial stability. However, from the review of existing literature, it can be observed that this hypothesis requires further extensions in three different aspects. First, recent development of a stock-flow consistent model of Minsky's financial instability hypothesis examines the role of government deficit and its implications on financial stability. Second, the Minskian hypothesis assumes a closed-economy model without the impact of movement of cross-border flows. However, as the crisis events in emerging economies (Latin American and East-Asian) revealed, financial stability in an economy is also to a large extent influenced by the impact of cross-border flows in open economies. Third, there has been reconsideration on the international policy front, whereby the role of financial institutional infrastructure in promoting financial stability in an economy and the role of the state in developing it, are being debated. All these extensions result in further dimensions to the pursuit of monetary policy by central banks, apart from the complementary role of regulations to monetary policy.

\section{Fiscal Deficit and Financial Instability}

While Minsky provided conceptual foundations for emphasis on effective regulatory policy instead of monetary policy, Godley and Lavoie (2007) focused on Stock Flow Consistent (SFC) Model for bringing into discussion the role of fiscal policy as the necessary, though not always sufficient, condition for achievement of major objectives of macroeconomic policy. In their view, the monetary economics "holds that a correct setting of interest rates is the necessary and sufficient condition for achieving non-inflationary growth at full employment, leaving fiscal policy rather in the air." They considered that such disregard of fiscal policy and the emphasis only on monetary policy is quite misplaced as, at least in theory, fiscal policy could achieve everything the central banks can be able to do through monetary policy for achieving economic stability. Using SFC model, they stated that "measured at current prices, the government's budget deficit less the current account deficit is equal, by definition, to private saving net of investment." The model was applied by Godley and Lavoie to US sectoral position at the end of the 1990s and beginning of the 2000s which depicted a public sector budgetary surplus, a trade sector deficit and a private sector deficit (Keen 2013). It was observed that as the objective of US authorities was to maintain a budgetary surplus (with emphasis on monetary policy for economic growth than on fiscal policy) and the US external trade balances resulted in growing deficit (as other economies tried to maintain trade surplus by investing in dollar reserves post 
the 1997 East Asian crisis), the levels of private sector deficit increased in years prior to 2007 to unsustainable levels. An interesting insight from SFC model therefore was that the rapid growth in bank finance was continuously funding the growing private sector deficit kicking in the Minsky’s Financial Instability Hypothesis into motion. However, unlike Minsky who focused on regulatory policy, Godley and Lavoie (2007) argued that this situation can be remedied through an active fiscal policy by allowing the government to increase public expenditure and run into deficit. This conclusion however is subject to certain presumptions - firstly, fiscal stance should be set in appropriate fashion at a well-defined level and growth rate (Godley and Lavoie 2007) and secondly, it should be applied in conditions in which households, firms, and financial institutions are seeking to increase savings (Kregel 2007). In such circumstances, through SFC model, Godley and Lavoie argued that even fiscal policy delivers sustainable full employment at a target inflation rate even at an arbitrary (though not correct) interest rate setting.

\section{Cross-border Flows and Financial Stability}

Kaminsky and Reinhart (2000) argue that the globalisation phenomenon in recent decades increased the inter-connectedness amongst nations. They argue that banking crises were relatively rare earlier due to capital and financial controls, but have increasingly become common since the 1970s often in tandem with currency crises. As nations and their financial systems are increasingly inter-connected through cross-border trade and capital flows, a shock in one part of the financial system spreads through the other parts through a series of global 'linkages'. The linkages generally include inter-bank claims and flow of information about market fundamentals. If these fundamentals are common to other markets, the expected returns, and hence, prices in those markets will also fall. Considering that it is optimal for banks to hold deposits in banks in other regions or sectors in order to provide liquidity if demand is unusually high, when one region suffers a banking crisis, the other regions suffer a loss because their claims on banks in the troubled region fall in value. If the spillover effect is strong enough, it causes a panic in adjacent regions. The panic gets stronger as it passes from region to region and finally becomes a contagion leading to a full-blown crisis (Allen and Gale, 2007; Kodres and Pritsker, 1998). Barton et al., (2003) argue that when the panic dimension collides with the inherent banking fragility, they set off a chain reaction and a country begins to spiral downward, as panic and loss of confidence increase problems in the banking system as well as the real economy at the macro-economic level. While Wolf (2008) therefore agreed with the role of 
leverage as proposed by Minsky as a valid explanation for financial crises, he did not buy into the argument that regulatory intervention could alone prevent them. Wolf (2008) argued that the pattern of global imbalances and associated policies also play a large role in setting the explosive charge, resulting in economies becoming highly fragile. The response, according to Wolf, is to call for limiting the scale of macro-economic imbalances, rather than regulatory intervention, since they frequently exacerbate the financial fragility.

\section{Financial Institutional Infrastructure and Financial Stability}

Minsky (1986, p 325) articulated that a number of historical facts, institutional attributes and policy thrusts must be integrated into any new foundation for economic policy. He favored a financial institutional structure in which emphasis on investment and economic growth is considered secondary to the emphasis on the role of employment as a policy objective. This debate on resilient institutional infrastructure in an economy for achieving financial stability and the role of central banks and other state agencies in its development, received greater academic attention after the recent global financial crisis (World Bank 2012). Institutional infrastructure primarily consists of credit reporting institutions (credit registries and bureaus), payment and settlement systems, and the legal framework that governs financial transactions. The argument of institutional infrastructure leading to financial stability is based on the principle that a welldeveloped financial infrastructure makes credit markets more efficient by reducing information asymmetries and legal uncertainties that may hamper the supply of new credit to the needy sections of the economy. This improves the depth of credit market transactions and broadens access to finance in a manner conducive to the achievement of employment as a policy objective. Institutional infrastructure further promotes financial stability in several ways. Transparent credit reporting can support the internal risk management of financial institutions and supply financial regulators with timely information on the risk profile of systemically important financial institutions. Similarly, well-designed payment and security settlement systems enhance financial stability by reducing counterparty risk in interbank markets and complex securities and derivatives transactions. Thus the recent academic thinking emphasises the effort required for the development of institutional infrastructure as a complementary objective to the pursuit of monetary policy by central banks. 


\section{e) Research Question and Research Methodology}

The previous sections dealt with Minsky's Financial Instability Hypothesis, which explained the inability of monetary policy as a tool to curtail bank finance during expansionary phases or as a tool for reviving economic growth during recessionary phases. Minsky argued that the pursuit of monetary policy should be complemented by instituting appropriate regulatory mechanisms by central banks so that the destabilizing forces in an economy can be modulated in a timely manner. Extensions to Minsky's hypothesis further apply emphasis on the complementary role of effective fiscal policy for achieving full employment, appropriate macro-economic policy for managing cross-border flows and policy for development of institutional infrastructure. The pursuit of these complementary policies alongside makes the pursuit of monetary policy a complex challenge to central banks, especially to those in emerging economies.

Against the above backdrop, this paper deals with the research question, "how does the Minskian Financial Instability Hypothesis and its subsequent extensions operate in the context of monetary policy-making by central banks of emerging economies?" The question is explored through the review of the decade-long experience of the RBI (from 2003-04 to 2013-14) spanning the periods before and after the recent global financial crisis. Subsequent sections of the paper deal with the interactions of monetary policy making at the RBI with other complementary policy pursuits in a step-by-step manner during this period.

\section{MONETARY POLICY DURING 2003-04 TO 2007-08}

This section analyzes developments in the first phase of monetary policy making at the RBI from the period 2003-04 until the period 2007-08, when Dr. Y.V. Reddy was the Governor of the RBI. During this period, the world economy entered into the global financial recession with the onset of the sub-prime crisis in the US during 2007-08. The crisis had seriously affected the growth prospects of emerging and advanced economies and posed unprecedented challenges for policy makers. However, ever since the financial crisis erupted, there has been an interest in RBI's management of the Indian financial sector that has facilitated growth and has yet maintained financial stability in the economy. This section attempts to analyse the Indian experience prior to the 2007-08 financial crisis, under the monetary stewardship of the RBI, using insights from Minsky’s Financial Instability Hypothesis. 
This section is organized as follows. It begins with an overview of developments in the Indian economy prior to 2007-08. From a Minskian perspective, it thereafter argues that the Indian financial sector withstood the financial crisis during 2007-08 due to the complementary use of regulatory policies alongside the pursuit of monetary policy by the RBI.

\section{a) Overview of the Indian Economy}

The period between 2003-04 and 2007-08 witnessed India as a significant player in world economy. Its contributions to both global output and growth and stability of the global economy have been monitored closely by both analysts and academics (Reddy 2011). The period witnessed what was possibly the highest average growth rate ever achieved by India, a moderate deficit regime (both in trade and fiscal terms) contributed essentially through domestic saving and investment, and the lowest average inflation since Indian independence (see Table 1 below). A lot of Indian enterprises ventured abroad during this period, leading to India's increased presence in the global economy. The Indian economy integrated with the world economy even on trade transactions as the imports and exports as a percentage of GDP, which was at $15 \%$ of GDP (exports and imports individually) during 2002-03 rose rapidly to about 24\% (imports) and 25\% (exports) of GDP in 2007-08 (World Bank 2012). Coupled with relaxations on foreign exchange convertibility (a process that began in the mid-1990s), the situation contributed to two-way capital flows. The economy on a whole appeared to be moving toward a stable growth phase.

Table 1 Select Macro-Economic Indicators of the Indian Economy (2003-08)

\begin{tabular}{|l|l|l|l|l|}
\hline Year & $\begin{array}{l}\text { GDP Growth } \\
\text { Rate }\end{array}$ & $\begin{array}{l}\text { Gross Fiscal } \\
\text { Deficit (\% of } \\
\text { GDP) }\end{array}$ & $\begin{array}{l}\text { Current } \\
\text { Account } \\
\text { Deficit (\% of } \\
\text { GDP) }\end{array}$ & $\begin{array}{l}\text { Wholesale } \\
\text { Price Index }\end{array}$ \\
\hline $2003-04$ & 8.0 & 4.34 & 2.3 & 5.5 \\
\hline $2004-05$ & 7.1 & 3.88 & $(0.4)$ & 6.5 \\
\hline $2005-06$ & 9.5 & 3.96 & $(1.2)$ & 4.4 \\
\hline $2006-07$ & 9.6 & 3,32 & $(1.0)$ & 6.6 \\
\hline $2007-08$ & 9.3 & 2.54 & $(1.3)$ & 4.7 \\
\hline
\end{tabular}

Source: RBI Handbook on Statistics of Indian Economy 2012-13 
The stable macro-economic growth even prompted the evolution of a fiscal responsibility regime with the enactment of the Fiscal Responsibility and Budget Management Act (FRBMA) in 2003. ${ }^{1}$ The fiscal improvements (see Table 1 above) subsequently resulted in a rise in total reserves (including gold and foreign exchange) from USD \$103.7 billion in 2003 to USD \$276.6 billion in 2007 (World Bank 2012). This had provided unprecedented import cover and also fed into other economic variables in a positive manner. The lowering of the government's fiscal deficit was accompanied by a benign inflationary environment, lower real interest rates, and a significant increase in private sector investment (refer to Table 2 below). It must be mentioned of course, that global economic conditions were also favorable during this period.

Table 2 Trend and Composition of Investments by Institutions

\begin{tabular}{|l|l|l|l|}
\hline Year & $\begin{array}{l}\text { Gross Capital } \\
\text { Formulation }\end{array}$ & $\begin{array}{l}\text { Public } \\
\text { investment }\end{array}$ & $\begin{array}{l}\text { Private sector } \\
\text { Investment }\end{array}$ \\
\hline $2003-04$ & $26.9 \%$ & $6.6 \%$ & $6.6 \%$ \\
\hline $2004-05$ & $32.8 \%$ & $7.4 \%$ & $10.3 \%$ \\
\hline $2005-06$ & $34.7 \%$ & $7.9 \%$ & $13.6 \%$ \\
\hline $2006-07$ & $35.7 \%$ & $8.3 \%$ & $14.5 \%$ \\
\hline $2007-08$ & $38.1 \%$ & $8.9 \%$ & $17.3 \%$ \\
\hline
\end{tabular}

Source: Government of India, June 2012 Report of the Working-Group on Estimation of Investment, its Composition and Trend for Twelfth Five-Year Plan (2012-13 to 2016-17)

Against this background, it would be relevant to examine Minsky's Financial Instability Hypothesis as it rejected the equilibrium methodology of mainstream economics as irrelevant in analyzing a real-world economy and instead argued that "stability is destabilizing." According to Minsky, relative tranquility gradually encourages more risk taking and innovative behavior that increases income even as it disrupts the conditions that generate coherence and tranquility. That is, the market forces that operate when a system is stable will push it toward instability, so that even if anything like equilibrium could be achieved, it would be offset by behavioral responses that would quickly move the economy away from equilibrium.

\footnotetext{
${ }^{1}$ FRBMA was enacted by the Parliament of India to institutionalize financial discipline, reduce India's fiscal deficit, and improve macroeconomic management and facilitate the overall management of the public funds by moving toward a balanced budget. The main purpose was to eliminate the revenue deficit of the country (building revenue surplus thereafter) and bring down the fiscal deficit to a manageable 3\% of the GDP by March 2008.
} 
Given a relatively stable phase in the economy during the period prior to 2007 , how did Minsky's hypothesis operate in the Indian context? In order to address this question, it is important to examine the policy stance of the RBI between 2003-04 and 2007-08 and understand how it steered through the stable phase in the macro-economy to maintain financial stability. The subsequent sections therefore describe the situation by providing three perspectives on the complementary role of regulatory policy pursued by the RBI alongside the pursuit of monetary policy during this period. First, the the counter-cyclical nature of regulations pursued by the RBI are outlined to explain the manner in which the RBI made the Indian banks prepare for periods of instability during the stable economic growth phase. Second, the comprehensiveness of coverage of regulated entities by the RBI during this phase is explained. Third, the manner in which regulations are pursued by the RBI in the area of financial innovation based on its comfort of market developments is outlined.

\section{b) Counter-Cyclical Regulatory Policies}

Minsky (2008 [1986], p. 280) stated that the "regime of regulation by the authorities...is intended to control the destabilizing forces inherent in banking and finance." This Minskian insight could be reflected in the RBI's experience during 2003-07, during which the policies of the RBI were aimed at achieving financial stability while maintaining growth momentum at reasonable levels, and giving a high priority to price stability. Some of the regulatory measures taken by the RBI during this period could be considered counter-cyclical (as they were taken when the environment was stable, which provided enough flexibility for monetary policy management). Some of these counter-cyclical measures organized in a chronological sequence below required the Indian banks to (Reddy 2008):

- Build up an Investment Fluctuation Reserve within a period of five years, based on a stress test conducted by the RBI (taking an increasing interest rate scenario, when the actual environment reflected decreasing interest rates) (2002);

- Put in place an effective credit administration mechanism (giving importance to documentation, collateral assessment, exposure limits, margin requirements) while extending real estate loans. This was supplemented with increase in risk-weights for real-estate exposures 
(while computing capital) initially from 100 to 125\% (July 2005) and further to 150\% (April 2006);

- Maintain a higher provision (from $0.25 \%$ to $0.4 \%$ ) on all standard (unimpaired) assets (except advances to Small Medium Enterprises and agriculture) (October 2005); and

- Compute capital with higher risk weight for consumer credit and capital market exposures from $100 \%$ to $125 \%$.

In particular, a summary of the gradual increase in the risk weights prescribed by the RBI while arriving at a capital adequacy ratio and the additional provisioning requirements for certain sensitive sectors identified by the RBI during the periods prior to the crisis (2004-2007) is summarized in Table 3 below.

Table 3 Countercyclical Prudential Regulation: Variations in Risk Weights and Provisioning Requirements

\begin{tabular}{|l|l|l|l|l|l|l|l|l|}
\hline Date & \multicolumn{2}{|l|}{ Capital Market } & \multicolumn{2}{l|}{ Housing } & \multicolumn{2}{l|}{ Other Retail } & \multicolumn{2}{l|}{$\begin{array}{l}\text { Commercial } \\
\text { Real Estate }\end{array}$} \\
\cline { 2 - 9 } & $\begin{array}{l}\text { Risk } \\
\text { Weight }\end{array}$ & $\begin{array}{l}\text { Prov } \\
(\%)\end{array}$ & $\begin{array}{l}\text { Risk } \\
\text { Weight }\end{array}$ & $\begin{array}{l}\text { Prov } \\
(\%)\end{array}$ & $\begin{array}{l}\text { Risk } \\
\text { Weight }\end{array}$ & $\begin{array}{l}\text { Prov } \\
(\%)\end{array}$ & $\begin{array}{l}\text { Risk } \\
\text { Weight }\end{array}$ & $\begin{array}{l}\text { Prov } \\
(\%)\end{array}$ \\
\hline $\begin{array}{l}\text { Dec- } \\
04\end{array}$ & 100 & 0.25 & 75 & 0.25 & 125 & 0.25 & 100 & 0.25 \\
\hline $\begin{array}{l}\text { July- } \\
05\end{array}$ & 125 & 0.25 & 75 & 0.25 & 125 & 0.25 & 125 & 0.25 \\
\hline $\begin{array}{l}\text { Nov- } \\
05\end{array}$ & 125 & 0.40 & 75 & 0.40 & 125 & 0.40 & 125 & 0.40 \\
\hline $\begin{array}{l}\text { May- } \\
06\end{array}$ & 125 & 1.00 & 75 & 1.00 & 125 & 1.00 & 150 & 1.00 \\
\hline $\begin{array}{l}\text { Jan- } \\
07\end{array}$ & 125 & 2.00 & 75 & 1.00 & 125 & 2.00 & 150 & 2.00 \\
\hline
\end{tabular}

Source: Address by Mr. Anand Sinha, Deputy Governor, RBI (2011)

In summary, the counter-cyclical approach adopted by the RBI is summarized by Dr. Reddy (2008, p. 14) in a manner resonating the Minskian insights as follows:

"While monetary policy influences aggregates, reality is often dis-aggregated. Hence, the RBI uses prudential regulatory policies to complement the monetary policy measures and objectives. It is pertinent that the lender of last resort function is not separate either from monetary and liquidity management or from financial regulation. Thus both monetary policy and prudential regulations are used as complementary tools to achieve the central bank objectives and they both support and reinforce each other." 


\section{c) Regulatory Coverage and Regulatory Comfort}

In addition to regulatory guidelines in the form of risk weights and risk provisions, the RBI's regulatory philosophy during the period prior to the crisis involved ensuring comprehensive regulatory coverage within the financial system and permitting certain business practices only based on regulatory comfort. Each of these aspects is explained below.

Regulatory coverage refers to the measures adopted by the RBI prior to the crisis to ensure that a) the regulatory regime effectively covers the usage of instruments of risk transfer so that risk does not merely pass from one institution to another without having intended prudential regulatory impact; b) the inter-connectedness amongst banks within the system is carefully monitored; and c) the non-bank financial companies (NBFCs) are also effectively brought into the regulatory ambit. As per the guidelines issued in February 2006, the RBI prescribed a conservative treatment of securitization exposures (which could be used as an instrument of risk transfer) for capital adequacy purposes, especially with regard to credit enhancement and liquidity facilities. Under these guidelines, banks are not permitted to recognize any profits on the sale of assets to the SPV immediately on sale, but over the life of the underlying securities issued. In December 2006, the RBI placed a major thrust on strengthening the regulatory framework with regard to NBFCs by way of a revised framework to address issues pertaining to the overall regulation of systemically important NBFCs and the relationship between banks and NBFCs. Finally, through its regulatory guidelines issued in March 2007, the RBI sought to limit the extent of inter-bank liabilities to a proportion of the bank's net worth and also restrict the extent to which they access the inter-bank call money market both as a lender and as a borrower.

Regulatory comfort continued to be one of the guiding principles of the RBI regulatory regime prior to the crisis. Regulatory comfort arises, especially in the context of financial innovation, when there is a need for synchronization between regulators' skills and sophistication required for financial markets. One of the proposals following the recent global financial crisis was that there is a need to improve regulatory skills in order to enable authorities to regulate the financial sector better. In opposition, Dr. Reddy (2011, p. 148) argued that "sophistication in financial sector should be permitted only to the extent that regulatory skills are able to manage." In other words, the approach of the RBI prior to the crisis was to restrict sophistication in financial markets, recognizing the skills to regulate them are difficult to build in developing countries like India in the short run. Accordingly, during the period prior to 2007, 
when innovative financial products such as derivatives were ruling the international financial system, RBI regulations did not permit Indian banks to enter into such products, except only with certain restrictions. For instance, the regulatory environment in which the Indian banks operate ensured that corporates are offered forex derivative products by banks only to hedge an underlying exposure and not to take any speculative position on the currency. Even when the RBI permitted certain forex derivative products, subsequently to a limited extent in 2007 , the RBI advocated the route of the central counter-party (CCP) arrangement for settling inter-bank exposures arising from such products. This was applicable even for the single-name credit default swaps that were permitted to be offered by Indian banks only after 2007. This approach of the RBI toward financial innovation largely resembled the Minskian prescription, as can be evidenced by the Dufrenoy Prize ${ }^{2}$ awarded to it in 2012 for its calibrated approach toward the introduction and regulation of financial products in India. The award mentions that the Indian regulatory approach followed by the RBI toward financial innovation is precautionary and gradual, with a culture of testing and paying attention to potential negative effects of sophisticated financial products before facilitating them.

\section{d) Monetary Policy and Regulatory Policy_Summary}

Through his writings on Minsky, Palley (2009) stated that a stable macro-economic environment transforms business institutions, decision-making conventions, and the structures of market governance including regulation. The stable macro-economic environment breeds euphoric times, which give birth to the philosophy of regulatory relaxation and increased risk taking. Regulatory relaxation makes the institutional structures, which were construed as thwarting mechanisms ineffective in a phase-wise manner (Ferri and Minsky 1991). First, the relaxation process begins with "regulatory capture," whereby regulatory institutions, such as central banks, are captured and weakened by industry participants. Second, it leads to "regulatory relapse," whereby the regulators are willing to liberalize the regulatory regime, built over a period of

\footnotetext{
${ }^{2}$ The Dufrenoy Prize for Responsible Innovation is an annual award instituted by the Observatory for Responsible Innovation. The Observatory - a MINES ParisTech Chair and an international independent think tank-was created with the purpose of thinking and debating new measures, concepts, and methods to foster responsibility in innovation. The MINES ParisTech was set up in 1783, and has had two Nobel Prize winners among its alumni in the last 25 years, apart from other eminent national and international personalities. Nominations for the Dufrenoy award were invited through the Observatory web site. A jury of international regulators, former professionals of the financial services industry, academics at the London School of Economics, and MINES ParisTech decided to bestow the award for 2012 upon the Reserve Bank of India for its outstanding approach to financial regulation (RBI 2012).
} 
time, on grounds that things are changed and current regulation is no longer needed. Third, it culminates in the process of "regulatory escape," whereby the supply of risk is increased through financial innovation that escapes the regulatory net because the new financial products and practices were not conceived when existing regulation was written. The processes of regulatory capture, regulatory relaxation, and regulatory escape ultimately result in increased risk taking by borrowers through unrestricted availability of bank finance (Palley 2009, p. 7-8).

Contrary to this, the way the RBI pursued its monetary policy during 2003-07 indicates its emphasis on regulatory policy as a complementary tool to monetary policy. There is a widespread recognition internationally that this complementary approach prevented Indian banks from excessive risk taking when internationally financial markets turned gradually volatile and turbulent. The RBI had therefore been asked to co-chair the G20 Working Group on Enhancing Sound Regulation and Strengthening Transparency (Working Group 1) along with the Canadian Ministry of Finance, and to contribute to strengthening international regulatory standards, enhancing transparency in global financial markets, and ensuring all financial markets, products and participants are appropriately regulated or subject to oversight, depending on their circumstances.

\section{MONETARY POLICY DURING 2008-09 TO 2012-13}

This section analyzes the experience of the pursuit of monetary policy by the RBI and of fiscal policy by the Government of India during the post-crisis period from 2008-09 to 2012-13. This period coincides with the governorship of the RBI under Dr. D. Subbarao from September 2008 until September 2013. This period is characterized by two phases. During Phase 1, which was the initial crisis management phase, monetary and fiscal policies were coordinated to provide required stimulus to the economy. As policy actions delivered required results and the economy averted a recessionary tendency, the subsequent phase was meant for withdrawal of stimulus measures. The RBI took steps toward withdrawl of expansionary monetary policy and adopted the path of tightening of interest rates from 2010-11. However, the fiscal policy pursuit by the Government of India continued to be expansionary for a relatively long period of time until the first quarter of 2013-14. The timing differences between these two policy measures (in terms of their withdrawal) resulted in an intervening period of high inflation, high interest rates and mounting twin deficits (on the trade and fiscal fronts). 
Against the above background, this section is organized as follows. It begins with the review of channels through which the 2007 financial crisis impacted the Indian economy and the measures taken by the RBI and the Government of India to contain the impact. The pursuit of fiscal policy and its impact on the economy is explained thereafter. Subsequently, the fiscal policy challenges faced by the RBI in the pursuit of its monetary policy for achieving price stability are presented.

\section{a) The 2007 Financial Crisis and the Indian Policy Response}

As outlined in the previous section, the Indian banking system remained relatively immune during the initial period due to the counter-cyclical regulatory measures taken by the RBI in the period prior to 2007. It was evident in the fact that Indian banks had hardly any direct exposure to the troubled assets in the epicentre of the financial crisis. However, considering the fact that the Indian economy was integrated with the global economy during years prior to 2007, India experienced the impact of the crisis, like many other emerging markets, through various channels - trade, financial flows and confidence. The experience of emerging economies during the 2007 crisis therefore prompted many economists to revisit the so-called "decoupling theory" in an increasingly globalized world (Kose et al. 2012). The impact of the crisis through various channels can therefore be explained as follows: the slump in export demand and tighter trade credit caused deceleration in aggregate demand; reversal of capital flows led to equity market losses and currency depreciations; global liquidity tightening resulted in lower external credit flows; and market rigidities and erosion of confidence led to the widening of credit spreads (RBI 2009). The crisis therefore led to a coordinated response by the RBI and the Government of India through monetary and fiscal policy measures.

On the monetary policy front, the RBI took measures to respond to the crisis which included (Reddy 2011) — a reduction in policy rates, a reduction in the bank reserves to be deposited with the central bank and the liberalization of export refinance facilities. The RBI had also reversed the counter-cyclical measures put in place until 2006 (in terms of higher risk weights and provisioning requirements) and asked banks to take action for the quick detection of weaknesses and a careful assessment of viability, and put in place, in a time bound manner, restructuring packages for viable accounts. In addition, in order to restore market confidence, the RBI opened up a swap window for banks for infusion of dollar liquidity, provided refinance facilities to apex institutions (to insulate small scale industries, export and housing sectors), 
provided refinancing facility to the non-bank sector (mutual funds and non-bank finance companies). Further, the RBI had also taken measures in the area of forex management by relaxing counter-cyclical policies earlier pursued by it with regard to access to external commercial borrowings. For instance, the RBI allowed non-bank finance companies to access foreign currency borrowing from multilateral financial institutions and government-owned development financial institutions. Corporates have been provided the flexibility to buy back the Foreign Currency Convertible Bonds (FCCBs) earlier issued by them. The RBI had actively used multiple instruments such as the liquidity adjustment facility (LAF), open market operations (OMO), cash reserve ratio (CRR) and securities under the market stabilization scheme (MSS) to augment liquidity in the banking system. In light of these measures, in a span of seven months between October 2008 and April 2009, there was unprecedented monetary policy activism (Reddy 2011), which resulted in a) reduction in the policy rate by 425 basis points to $4.75 \%$; b) reduction in the cash reserve ratio (CRR) by a cumulative 400 basis points to $5.0 \%$; and c) the actual/potential provision of primary liquidity was of the order of $10.5 \%$ of GDP. These measures ensured speedy restoration of orderly conditions in financial markets within a short time span.

Considering the soundness of Indian banking system in the years preceding the crisis and the monetary policy support during the crisis, fiscal policy did not have to support the banking sector in the form of capitalization/financial bailout, which was rampant in most advanced economies. The Government of India therefore responded through fiscal stimulus packages in the form of additional public spending, tax cuts, government guaranteed funding for infrastructure spending, expanded guarantee cover for credit-to-micro and small enterprises, additional support to exporters and increased expenditure on government consumption. This led to an expansionary fiscal stance, which begin in 2008-09 and continued in the years thereafter. In order to allow the statutory flexibility to pursue these measures, the central government invoked emergency provisions of the FRBMA to seek relaxation from fiscal targets for launching the fiscal stimulus packages. Thus, the fiscal response has been highly weighed toward containing the economic slowdown by raising aggregate demand through discretionary counter-cyclical fiscal policy. Such a fiscal policy stance was consistent with Minskian views that in situations of deep and prolonged economic downturn, as in the present context, fiscal policy could play a leading role in stabilization. The fiscal stimulus measures have largely 
achieved the objective of containing the economic slowdown in the short term as reflected by a growth revival during 2009-10.

The pursuit of both monetary and fiscal policies immediately after the crisis thus represented a coordinated policy response. However, the timing of exit strategies from these stimulus responses were different with monetary policy taking the lead in reversing the expansionary stance prior to the fiscal policy tightening that took place subsequently. In the intervening years, therefore the country witnessed certain macro-economic vulnerabilities which are outlined in subsequent paragraphs.

\section{b) Fiscal Policy After the 2007 Crisis}

The pursuit of fiscal policy from 2008-09 should not only be analyzed in the backdrop of the financial crisis that occurred mid-way during the year, but also keeping in perspective that the country had undertaken general elections of the central government in May 2009. Therefore, the fiscal stimulus measures in response to the crisis were largely on top of an already expanded safety net for the rural poor, a farm loan waiver package, and salary increases for government staff (Reddy 2011). This led to a sudden surge in the fiscal deficit of the Government of India to $5.9 \%$ in $2008-09$, and it continued to rise to $6.4 \%$ in $2009-10$. However, there was slippage in the fiscal deficit in 2010-11 to 4.79\%, largely due to the one-off revenue windfall through spectrum auctions and divestments. The fiscal deficit thereafter went up to 5.82 considering factors such as over-dependence of government on non-durable sources of revenue, inadequate pruning of subsidies, and mounting interest burden on government debt (see Table 4 below). These aspects are further analyzed in the subsequent paragraphs.

Table 4 Key Indicators of India's Fiscal Position (2008-09 to 2011-12)

\begin{tabular}{|l|l|l|l|l|l|}
\hline Year & \multirow{2}{*}{$\begin{array}{l}\text { Gross } \\
\text { Fiscal } \\
\text { Deficit- }\end{array}$} & \multicolumn{3}{|l|}{ Revenue-GDP ratio } & \multicolumn{2}{|l|}{$\begin{array}{l}\text { Expenditure to subsidies } \\
\text { and interest payments as \% } \\
\text { of GDP }\end{array}$} \\
\cline { 3 - 6 } & GDP & Tax & Non-Tax & Subsidies & Interest \\
\hline $2008-09$ & 5.99 & 10.72 & 1.72 & 2.30 & 3.41 \\
\hline $2009-10$ & 6.46 & 9.59 & 1.79 & 2.18 & 3.29 \\
\hline $2010-11$ & 4.79 & 10.12 & 2.80 & 2.22 & 3.00 \\
\hline $2011-12$ & 5.75 & 9.86 & 1.36 & 2.43 & 3.04 \\
\hline $2012-13$ & 5.20 & 10.32 & 1.29 & 2.57 & 3.16 \\
\hline
\end{tabular}

Source: RBI Handbook on Statistics of Indian Economy 2012-13 
The Indian fiscal indicators, such as those depicted above, demonstrate that the tax and non-tax revenue contribution to the government exchequer was largely dominated by the latter indicating a non-durable nature of government deficit financing. In fact, at a tax-GDP ratio of around $10 \%$, India has one of the lowest ratios, even as lower middle-income countries had taxGDP ratios of above 15\%. Even among G20 countries, India had the third-lowest tax base before Mexico and Indonesia, with a major portion of tax revenue coming from indirect taxes indicating a regressive taxation regime in the country (World Bank 2012). Three reasons are generally cited for these low tax-GDP levels in the country (Moody 2011). First, structural factors such as low average incomes and a high poverty rate result in a very small portion of the labor force being eligible to pay personal income taxes. Second, in light of various exemption and compliance issues, a large portion of profit earned by economic activities of small and medium enterprises (SMEs) are not fully tapped into the taxation net. Third, there is lack of non-conventional tax policy initiatives to improve tax collection (for instance the agricultural income in India is tax free; service tax collection does not contribute significantly to the national exchequer). Thus the fiscal deficit financing in the country relies significantly on non-tax revenues, which are non-durable in nature.

On the expenditure side, subsidies constitute a major source of fiscal risk. The Government of India has long embarked on the path of subsidizing key commodities such as petrol/ diesel, fertilizers, and food. Subsidies are used as a fiscal policy tool to significantly even out the volatility that otherwise could emerge, for instance, in the case of petrol/diesel and fertilizers, if the full pass-through of global fuel price shocks to domestic prices was allowed. While subsidies could thus be a tool for inflation management in the short term, it poses a significant fiscal burden due to persistent high prices in international markets (RBI 2009). In addition, the food subsidy has increased substantially in recent years on account of a widening gap between the central issue price of wheat and rice and the economic cost of delivering these food grains. Debate on subsidies also raises concern regarding the way they proliferated over a period of time, owing to reasons such as: expanse of governmental activities, relatively weak determination of governments to recover costs from respective users of subsidies (even when this may be desirable on economic grounds), and relatively low efficiency levels of governmental activities leading to leakages in the administration of subsidies to the end-users (Kelkar Committee 2012). 
Thus, on one hand, there is dependence on non-durable sources of revenue, and on the other hand, there is fiscal burden of mounting subsidies, thus rendering the objectives and aspirations of an effective fiscal policy largely unachieved. This results in mounting government debt (details of this are covered in the subsequent section) on which the interest payments constitute another major source of fiscal burden. Together, subsidies and interest payments account for the largest contributors to India's fiscal deficit. These structural aspects of fiscal deficit led to a situation where India appeared as a major outlier in terms of fiscal indicators during 2011-12 (second only to Egypt among 27 major emerging markets) leaving the least room for continuation of a counter-cyclical fiscal policy response (IMF 2012). Recognizing the gravity of the situation, the Government of India has constituted a committee to draw a road map for fiscal consolidation — the Kelkar Committee - which submitted its report in September 2012. The Committee noted in its report about the fiscal situation during 2011-12 as follows:

"The Indian economy is presently poised on the edge of a fiscal precipice, making corrective measures aimed at speedy fiscal consolidation an imperative necessity if serious adverse consequences stemming from this situation are to be averted in an efficient and timely manner."

\section{c) Fiscal Policy Implications on Monetary Policy}

As outlined in the literature review section, increased fiscal deficit has the potential to result in an alarming level of government public debt and pose macro-economic vulnerabilities in the form of inflation, reduce room for monetary policy stimulus, increase the risk of external sector imbalances, and dampen private investment, growth and employment (Blinder 1982).

In the Indian context, the above conclusions were summarized in the RBI's Report on Currency and Finance for the period 2009-12 (released in December 2012), which analyzed the issue of "Fiscal-Monetary Co-ordination" in a detailed manner. The report outlined two key challenges to monetary policy with increased fiscal deficit: an increase in net market borrowings of the government with a crowding-out effect on private investment, and high inflation due to supply-side impacts on market prices. These challenges therefore rendered little scope for monetary policy effectiveness in reviving economic growth further in the Indian economy, post2010-11. These issues are explained in the following paragraphs with the help of certain public finance indicators of the Indian economy as presented in Table 5 below: 
Table 5 Public Finance Indicators (2008-09 to 2012-13)

\begin{tabular}{|l|l|l|l|l|}
\hline Years & $\begin{array}{l}\text { Gross Fiscal } \\
\text { Deficit * }\end{array}$ & $\begin{array}{l}\text { Net Market } \\
\text { Borrowings } *\end{array}$ & Inflation & $\begin{array}{l}\text { Trade Deficit } \\
*\end{array}$ \\
\hline $2008-09$ & 5.99 & 4.39 & 8.1 & $(2.3)$ \\
\hline $2009-10$ & 6.46 & 6.11 & 3.8 & $(2.8)$ \\
\hline $2010-11$ & 4.79 & 4.25 & 9.6 & $(2.8)$ \\
\hline $2011-12$ & 5.75 & 5.47 & 8.9 & $(4.2)$ \\
\hline $2012-13$ & 5.20 & 4.75 & 7.4 & $(4.8)$ \\
\hline
\end{tabular}

* as percent of GDP

Source: RBI Handbook on Statistics of Indian Economy 2012-13

First, the impact of increased fiscal deficit is seen in the corresponding increase in net market borrowings of the government to finance the same. The borrowing requirements added debt management pressures to the RBI, which also plays the role as a banker to the government apart from managing liquidity requirements of economy. Market borrowings are generally met through issuance of government securities (subscribed by banks and financial institutions to meet their Statutory Liquidity Ratio requirements) as well as through RBI credit to the government. Therefore certainty and planning of government borrowings and how well the government adheres to the plan critically determine the available credit in the economy. However, as the RBI report (2009) indicated, during 2008-09 the increase in market borrowings substantially exceeded the projected levels in view of stimulus measures. This situation continued in 2009-10, though in 2010-11, with one-off receipts from 3G spectrum auctions, the borrowing requirements were substantially lower than projected levels. However, in 2011-12, while the projections of both the RBI and government initially were consistent, the actual borrowings far exceeded the projections, largely due to fiscal slippages in the form of increased public expenditure and overshooting of subsidies. This fiscal slippage, termed by the RBI as "unprecedented" (RBI 2009 p. 54) led to a situation of fiscal dominance on monetary policy with constraints on its attempt to pursue an expansionary stance, even during the periods of reduced GDP growth during 2011-12 and 2012-13.

In order to understand the operational aspects of fiscal constraint on monetary policy, it would be important to examine the inflationary trends in the Indian economy following the 2007 crisis. As stimulus measures led to an expansionary monetary policy in the initial years after the crisis, the growth process entrenched, but led to a resurgence of inflationary pressures. The RBI, therefore, exited the accommodative monetary policy, which it pursued until October 2009, and 
adopted a more calibrated approach between January 2010 and October 2011. This led to high interest rate levels in the economy, adding up pressure on the RBI to reverse the monetary policy stance. Such demands were also put forward from various quarters considering the fact that the economy resurfaced downside risks to economic growth in the second half of 2011-12. However, the RBI in its 2009 report indicated that monetary policy will generally be constrained from reducing interest rates in two situations that characterized the current state of the Indian economy - the need for financing the fiscal deficit and the structural nature of inflation.

It is generally argued that the fiscal deficit through its crowding out effect leads to an increase in the price level in the economy with a corresponding reduction in the overall output. In such a situation, even if the monetary authority decides to offset the impact of higher interest rates by increasing the money supply, it may not increase the output but it may push up the price level in the short run (Sargent and Wallace 1981). This is because a reduction in monetary financing in the short run would imply more bond financing, which would push up interest rates. This, in turn, would lead to higher interest payments and, thus, larger budget deficits over time. Given the perceived limits to the government's ability to service a progressively higher order of bond obligations, monetary financing would be inevitable and large eventually, which would have inflationary consequences. On the other hand, the Indian experience with inflation suggested that "food" and "fuel" prices constitute significant components, which increase the rate of inflation measured by Wholesale Price Index in the economy. As these are supply-side price shocks that are not transitory in nature, conventional monetary policy tools to deal with inflation management (such as a reduction in interest rates) might not be effective (Mohanty 2010).

\section{d) Monetary Policy and Fiscal Policy-Summary}

During 2010-11/2011-12, the mix of expansionary fiscal policy and contractionary monetary policy therefore led to high interest rates on one hand and has placed a constraint on the RBI to reduce them further, on the other hand. The RBI therefore has outlined the need for pursuing the path of fiscal consolidation by the government, through its Half-Yearly Financial Stability Reports (RBI FSR 2013 and RBI FSR 2014). The government responded to the situation by constituting the Kelkar Committee for drawing out a road map for fiscal consolidation, which submitted its report in September 2012. However, pending the implementation of the committee 
recommendations, the economy witnessed a period of a high level of fiscal deficit, a high level of interest rates, and a high level of inflation during the period up to 2012-13.

\section{MONETARY POLICY SINCE 2013-14}

As outlined in the literature review section, the SFC model (presented as an extension of Minskian hypothesis by Godley and Lavoie 2007) states that "measured at current prices, the government's budget deficit less the current account deficit is equal, by definition, to private saving net of investment." In its mathematical form, this translates to:

Government Budgetary Surplus (i.e. Revenues less Expenditure) = Trade Sector Deficit (i.e., Imports less Exports) + Private Sector Deficit (i.e., Savings less Investment)

On one hand, this equation was used to predict the financial crisis of 2007, wherein the continuous budget surpluses prior to 2007 resulted in a period of increasing private sector deficits, which were financed through bank credit and led to financial instability in the US economy. On the other hand, the conclusion from this equation could also imply that, given a certain level of private savings, an increase in the government deficit will have to be balanced by either a reduction in private investment or an increase in trade deficit. This results in the confrontation of central banks with the problem of "impossible trinity," which states that it is impossible for a central bank to have all three of the policy goals following at the same time: a) exchange rate stability; b) free capital movement (absence of capital controls); and c) an independent monetary policy (Aizenman 2010).

Confrontation with the impossible trinity meant that the need for the RBI to maintain a particular level of interest rates in the economy (pursuant to fiscal challenges as discussed above) and its commitment to ensure free capital flows, restricted its ability to manage exchange rate stability in an effective manner. In such a situation, the exchange rate stability largely depends on market movements. In such a vulnerable situation, even a small trigger would precipitate episodes of currency volatility. In the Indian context, the trigger came in the form of an announcement by the Chairman of Federal Reserve in May 2013 that it will begin to taper quantitative easing (QE) in coming months. The statement by Federal Reserve sent shock waves across emerging markets including India. This has resulted in two important outcomes relevant to the monetary policy making by RBI. First, the market developments after the Federal Reserve 
statement resulted in a period of extreme volatility of Indian currency during July/August 2013 and exposed the challenges of exchange rate management on monetary policy. Second, the episode coincided with the changing of the guard at the helm of the RBI (with Dr. Raghuram Rajan taking over as the 23rd Governor of RBI on September 4, 2013), and led to the pursuit of structural reforms of the banking sector under the governorship of Dr. Rajan taking the pursuit of monetary policy to an enhanced level. Each of these two aspects are explained below.

\section{a) Monetary Policy and Exchange Rate Management Policy (May-August 2013)}

The statement by the Federal Reserve Chairman in May 2013, regarding the plan for tapering its QE program, triggered capital outflows from India, particularly from the debt segment, in view of common perception of international investors about the ability of emerging economies to withstand reversal of capital flows from these economies. Coupled with a substantial slowdown in capital inflows, the Indian rupee experienced significant depreciating pressure from the second half of May 2013. The Indian rupee depreciated sharply by around $19.4 \%$ against the US dollar between May 22, 2013 when it stood at 55.4 per US dollar and August 28, 2013 when it touched historic low of 68.85 per US dollar. The depreciation came on the back of sharp reversals in capital inflows, coupled with a weak macroeconomic environment in the form of a sharp deceleration in GDP growth rate (4.5\% in 2012-13 and 4.4\% in Q1 of 2013-14), high inflation (WPI inflation of 7.4\% in 2012-13), and large fiscal deficit (4.9\% of GDP in 2012-13). The macro-economic situation from an external perspective also had structural issues that led to the rupee fall during this period. For instance, the current account deficit in India had reached an unsustainable level (4.8\% of GDP in 2012-13) primarily as a result of slowdown in global growth, which has reduced demand for Indian exports. On the other hand, the share of gold in total imports increased since 2007-08 and was close to 3\% of GDP in 2012-13. All these situations led to annualized daily volatility in the INR-USD exchange rate during May 23 to September 4, 2013, comparable to very few historical volatile episodes (see Table 6 below): 
Table 6 Annualized Daily Volatility in INR-USD Exchange Rate During Various Episodes of Volatility (1993-2014)

\begin{tabular}{|l|l|l|}
\hline Period & $\begin{array}{l}\text { Volatility } \\
(\mathbf{\%})\end{array}$ & Reason \\
\hline End-Jan-Feb 1996 & 13.94 & Impact of Mexican Crisis \\
\hline Aug 1997 to Jan 1998 & 7.91 & Impact of East-Asian Crisis \\
\hline May to Aug 1998 & 7.63 & Impact of East-Asian Crisis \\
\hline Sep to Nov 2008 & 13.37 & Impact of Global Financial Crisis \\
\hline May 23 to Sep 4 2013 & 17.14 & Impact of Federal Reserve Announcement \\
\hline
\end{tabular}

Source: Anand Prakash (2012)

The exchange rate position posed macro-economic challenges, which prompted the RBI to address the situation initially through monetary policy tools. In a move to reduce speculative trading in the dollar and to cut forward positions of banks, the RBI increased the marginal standing facility rate (short-term rate at which banks borrow from the RBI using their statutory liquidity ratio securities as collateral). Further, the RBI had also capped the amount banks can borrow from overnight markets to INR 75,000 crore and announced open market sales of bonds in order to suck liquidity from the system through a monetary policy route. It was expected that with these measures bond prices would fall and yields would rise, attracting foreign investment back into the debt market at a time when foreign institutional investors (FIIs) sold billions of dollars ever since the US Fed signalled a tapering of QE. However, on the contrary, these sudden measures resulted in some collateral damage - a spike in short-term bond rates and firming up of the long-term yield curve, after July 15, 2013. This resulted in an inverted yield curve position in the bond market (with inversion of $230 \mathrm{bps}$ ), which has happened only twice before since 2000 (in 2008 (of 60 bps) and in 2012 (of 30 bps), which lasted only for brief period). The RBI therefore immediately took corrective steps in August 2013, aimed at twin purposes; preventing the decline in long-term bond yields and issuing regulations for shielding banks from incurring financial losses due to declining bond prices.

As monetary policy became ineffective in influencing exchange rate movements, the RBI turned to certain unconventional measures in exchange rate management in September 2013, when Dr. Rajan took over as Governor of the RBI. In this context, it is important to outline that the RBI's stated policy with respect to exchange rate management, is that it is not guided by a fixed or pre-announced target or band. However, the RBI retained the flexibility to intervene in the market to manage excessive volatility and disruptions to macroeconomic stability and to take relevant measures. Continuing its stated objective, the measures taken by 
the RBI in the current episode included the following: attracting the flow of foreign currency deposits from non-resident Indians (with maturity of three years and above) through increased interest rates (arising from concessions offered by the RBI, such as swapping facility of such deposits with the Reserve Bank and exemptions from mandatory cash/statutory reserve requirements and directed lending programs); allowing additional avenues to borrowers for availing external commercial borrowings from their foreign equity holder companies without specific permission from the RBI; a foreign exchange swap program for oil marketing companies (OMCs); and increasing the overseas borrowing limit of banks from 50 to $100 \%$ of the unimpaired Tier I capital (with the option of a swap with the RBI). The RBI had also taken additional measures, in the form of expansion of bi-lateral currency swap arrangements with Japan, and steps for rationing gold imports (placing restrictions on gold imports by banks). In addition to these administrative measures, the RBI tightened its monetary policy as an immediate measure to shield against volatility emanating from the Fed's intention to taper its bond purchase program.

The measures taken by the RBI were supplemented by the Government of India by continuing the fiscal consolidation process in 2013-14, which it had initiated in 2012-13. The slowdown in economic growth affected tax collections, particularly indirect tax collections. Further, the market conditions were not conducive to meeting disinvestment targets. However, the government pursued the path of fiscal consolidation through a sharp cutback in "plan" expenditures and higher receipts of non-tax revenues that may not be recurring in nature. Incidentally, the second half of 2013-14 witnessed a good monsoon season which had boosted the prospects of the agriculture season and improvements in economic growth. The government also had taken steps in clearing projects, especially in the infrastructure sector in order to improve the overall investment climate. Coupled with developments in the external sector (outlined in subsequent paragraphs), the year 2013-14 finally registered a fiscal deficit of 4.5\% of GDP versus 4.9\% in 2012-13 (Government of India 2013).

The policy measures both on the fiscal and monetary front met with modest signs of improvement in the macro-economic environment during August 2013 to March 2014. During 2013-14 exports were valued at USD \$312.6 billion, registering a growth of 4.1\% over the level of USD $\$ 300.4$ billion in 2012-13. The value of imports during 2013-14 was USD $\$ 450.1$ billion, showing a decline of $8.3 \%$ compared with the level of USD $\$ 490.7$ billion in the corresponding period of 2012-13 (RBI FSR 2013). The increase in exports during the period 
was facilitated by modest recovery in key partner economies and the depreciation of the rupee during early part of the year. Further, there was robust demand for software exports, which also had improved earnings from invisibles. On the other hand, measures taken by the RBI and the government led to the focus on rationing imports, especially in curtailing non-essential imports (such as gold). This led to improvement in the trade balance and the current account, which was under stress since 2011-12, and was brought to a sustainable level during 2013-14, and the current account deficit fell from 4.7\% during 2012-13 to 1.7\% during 2013-14 (RBI FSR 2014). Improvement in the current account balance, along with strong capital inflows (particularly NRI deposits), accretion to foreign exchanges reserves led to stability of the exchange rate and improved the external sector's resilience by the time the Fed finally announced tapering in its bond purchase program on December 18, 2013. All these developments finally led to the recovery of a daily exchange rate of the rupee to 60.10 per USD (on March 28, 2014) compared to the 68.85 per USD (on August 28, 2013).

\section{b) Monetary Policy and Policy for Enhancing Financial Institutional Infrastructure (Since September 2013)}

The announcement of tapering by the Federal Reserve in December 2013, and subsequent macro-economic developments, led to the assessment of financial stability primarily with reference to the domestic banking sector by the RBI. In the Half-Yearly Financial Stability Report published during that month, the RBI underscored that risks to the banking sector (as measured by its Banking Stability Index, or BSI) were increased. The BSI is a measure used by the RBI to assess distress dependencies within the banking sector based on co-movements in banks' equity prices. It measures the expected number of banks that could become distressed given that at least one bank becomes distressed. As indicated in the FSR, the BSI depicted a rising trend beginning September 2010, moderated during first half of 2013 and again reversed the trend in August 2013, indicating escalation in common distress in the banking system.

The expected distress in the banking sector translates into possible strain on asset quality of banks. Some of the factors identified by the RBI as affecting the asset quality adversely included - current economic slowdown (global and domestic), persistent policy logjams, delayed clearances of various projects, aggressive expansion by corporates during the boom phase with resultant excess capacities, and deficiencies in credit appraisal at banks. While there are sectors such as retail that witnessed growth, it was primarily observed in the FSR that a few 
sectors, namely, Infrastructure, Iron \& Steel, Aviation, Textiles and Mining continue to contribute significantly to the problem assets of the banking sector. Through macro-stress tests, the RBI further observed that if the adverse macroeconomic conditions persist, the credit quality of commercial banks could deteriorate further. In such situations, the existing level of impairment provisions of commercial banks was not perceived to be sufficient to meet the expected losses.

The issue of strengthening the domestic banking sector and making it resilient amidst the global macro-economic developments therefore became the concern of the RBI under the governorship of Dr. Rajan, who took over on September 4, 2013 amidst the currency volatility externally and a vulnerable macro-economic outlook domestically. Dr. Rajan was credited in academic circles for his assessment of financial development making the world risk riskier, through a paper presented at the Jackson Hole Conference in 2005. Dr. Rajan argued that technological change, market liberalization and institutional change facilitated the evolution of the financial sector in recent times, but had simultaneously provided incentives for banks to produce bad outcomes. His paper served as a wakeup call to regulators to periodically recognize the existence of perverse incentives that were present in the financial sector. Dr. Rajan called for changes to incentives of financial managers by adopting a risk-management approach to financial regulation. In a subsequent work published in 2010 Rajan argued that, in the absence of such regulatory framework, incentive structures thrown up by the environment and the state of competition in the market make front-line managers at banks pursue aggressive risk-taking strategies, a practice which top management has little reason to curb.

Following his academic research, Dr. Rajan focused on strengthening the domestic banking sector and on sustaining financial stability in the long run by implementing financial sector reforms aimed at improving the financial institution infrastructure within the country. Incidentally, the blue-print for these financial sector reforms were laid down by Dr. Rajan himself through a Committee on Financial Sector Reforms constituted by the Government of India. The committee report, submitted in 2008 , articulated that the country need to undertake financial sector reforms for at least three reasons: 1) to include more Indians in the growth process; 2) to foster growth itself; and 3) to improve financial stability, flexibility, and resilience, and thus protect the economy against the kind of turbulence that has affected emerging markets in the past, and is affecting industrial countries today. Echoing the Minskian perspectives of enhancing the institutional infrastructure to promote financial stability, the 
committee report stated that, "the role of the government is not to take on the tasks that should legitimately be delegated to the private sector, but to create an enabling environment by building sound financial infrastructure."

In order to ensure that such a steering of a new financial structure in the economy is undertaken in a calibrated manner, Dr. Rajan announced a five-pillar framework in November 2013 that is set to guide the development of RBI financial sector policies. Under this framework, first, the RBI is expected to focus on improving the banking system's ability to deal with corporate distress and financial institution distress by strengthening real and financial restructuring as well as debt recovery. Second, in order to achieve this, it was proposed under the framework that the RBI will strengthen banking structure through new entry, branch expansion, encouraging new varieties of banks, and moving foreign banks into better regulated organizational forms. Third, this move towards a new banking structure is supplemented with the objective to broaden and deepen financial markets and increase their liquidity and resilience so that they can help allocate and absorb the risks entailed in financing India's growth. Fourth, considering the role of banks in broader national economic development through large-scale financial inclusion, the framework also outlined its focus on expanding access to finance to small and medium enterprises, the unorganized sector, the poor, and remote and underserved areas of the country through technology, new business practices, and new organizational structures. Apart from the above measures, the fifth and the important pillar that is articulated under the new framework of the RBI relates to clarifying and strengthening the monetary policy framework. ${ }^{3}$

Pursuant to the five-pillar framework, the RBI has so far issued regulatory guidelines that focused on the creation of a framework for revitalization of distressed assets, instituting measures for the creation of a database of large corporate credits and focusing on the early sharing of credit information amongst bankers to ensure that they take all possible steps to ensure that borrowers do not slip off into the non-performing category once early warning

\footnotetext{
${ }^{3}$ Toward this direction, immediately after assuming office, Dr. Rajan constituted an Expert Committee to revise and strengthen the monetary policy framework of the RBI. One of the stated terms of the Expert Committee, consistent with the discussions outlined in this section, relate to the identification of regulatory, fiscal and other impediments to monetary policy transmission, and recommending measures and institutional pre-conditions to improve transmission across financial market segments and to the broader economy. The Expert Committee submitted its report in January 2014. The recommendations are currently being reviewed and implemented by the RBI and therefore kept outside the scope of this Paper.
} 
signals are appropriately identified by at least one of the bankers. A blueprint for the new banking structure for India is also released by the RBI wherein the concept of new banks (payment banks and small banks) was proposed for public discussion. The RBI has set up internal committees for guiding monetary policy making and for strengthening the corporate governance at banks, the recommendations of which are currently being reviewed for implementation. Restructuring human resources at the RBI to equip them with challenges of macro-economic and financial stability is also an incidental objective outlined by Dr. Rajan while articulating the manner in which the five-pillar framework is going to be implemented by the RBI in the coming months.

The steps taken by the RBI in recent months under the governorship of Dr. Rajan thus reflect Minskian insights of viewing central banking as a "learning game" for affecting the performance of a changing system. In such a game, according to Minsky, "central banking can be successful only if central bankers know how the institutional structure at banks behave for sourcing its funding and correctly assess how this behavior affects the system" (Minsky 2008 [1986], p. 359). In other words of Minsky, central banks "have to steer the evolution of the financial structure" (Minsky 2008 [1986] p. 359). The five-pillar framework of Dr. Rajan is aimed at such an evolution of new financial structure within the economy, the success of which is to be tested in future.

\section{c) Monetary Policy, Exchange Rate Policy and Financial Infrastructure-Summary}

The previous paragraphs outlined constraints of monetary policy in containing the impact of the cross-border flows in emerging economies. The experience of the RBI since 2013-14 highlighted vulnerabilities to monetary policy decisions of central banks of emerging economies arising from the spill-over impact of cross-border flows. This experience further demonstrates the need for coordinated action by domestic governments alongside the monetary policy steps taken by their local central banks in order to achieve macro-economic stability of the economy. It also underscored the steps taken by the RBI to strengthen the domestic banking sector and equip it with a sound financial infrastructure in order to ensure that macro-economic stability should eventually translate into financial stability in a sustainable manner in the long run. 


\section{CONCLUSION}

Minsky once stated that the mainstream economic theory argues that the central bank authorities should:

"focus on the money supply and should operate to achieve a constant rate of growth of this construct. The authorities in large part accept the validity of this view. As a result, officials making monetary policy wear blinders that restrict their vision, so they tend to ignore the financing relations by which monetary phenomenon affect activity. The money-supply blinders worn by the authorities in effect dismiss the ways in which portfolio transformations occur and how they affect the stability of the economy." (Minsky 1986 (2008) p 280).

Minsky's Financial Instability Hypothesis therefore argues against placing excessive reliance on the ability of monetary policy to attain financial stability in the economy. Instead, as per the hypothesis, central banks should remove the money-supply blinders and in turn focus on the forces that introduce endogenous instability into the economy and work toward containing their impact on the growth of the economy by introducing "conventions, constraints and interventions into the environment" (Ferri and Minsky 1991, p. 21). It therefore translates in the Minskian analysis and its subsequent extensions (outlined in the literature review section) that the role of monetary policy should be supplemented with other policy choices that can be pursued by central banks and governments.

The Indian experience of the previous decade as reviewed in previous sections underscores this important Minskian insight. In this section, an attempt to draw a conclusion has therefore been made regarding certain challenges to the monetary policy-making in emerging economies considering the dynamic interactions of monetary policy with other policy options at the disposal of central banks and governments. Each of these conclusions is explained below.

\section{a) Counter-Cyclical Regulatory Policy Compliments Monetary Policy}

In order to prevent the economy from experiencing periods of financial instability, Minsky's Financial Instability Hypothesis calls for the pursuit of effective counter-cyclical regulatory policy in addition to monetary policy. The Indian experience provides empirical evidence to support this Minskian construct, as the period prior to 2007-08 witnessed the pursuit of an effective regulatory policy insulating the domestic banking system from the financial crisis of 2007-08. However, the Indian experience further revealed that regulatory policy effectively 
compliments monetary policy, only during periods of economic growth, which is characterized by an effective fiscal policy. This leads to an implicit conclusion that the effectiveness of monetary policy is determined not just by the regulatory policy support, but the support that it should receive from fiscal policy in a counter-cyclical manner. There is a need therefore to undertake further academic research focusing on this trilateral relationship between monetary, fiscal and regulatory policies.

\section{b) Pro-cyclical Fiscal Policy Presents Challenges to Monetary Policy}

Extensions to Minsky's hypothesis through a Stock-Flow Consistent Model (SFC) argue that fiscal policy could play an effective role in reviving the economy as much as it can be done through pursuit of monetary policy. This is evident in the post-crisis Indian experience where the coordinated monetary and fiscal policies provided an effective direction for the revival of the Indian economy and restore economic growth during 2009-10. However, the pursuit of fiscal policy, even when the economy revived growth, represented a pro-cyclical fiscal policy which posed constraints to the operation of monetary policy.This resulted in a high rate of inflation, and high levels of interest rates in the economy. The Indian experience thus underscores the challenges that the monetary policy implementation encounters when it is confronted by fiscal dominance. The experience demonstrated that in such circumstances, the ability of the central bank to influence the monetary policy outcomes is rather constrained.

\section{c) Exchange Rate Policy Adds Another Dimension to Monetary Policy}

On one hand, pro-cyclical fiscal policy places constraints on monetary policy, and on the other hand, it results in trade deficit financing an important aspect of foreign exchange rate management. Trade deficits, when fiscal deficits are on constant rise, need to be financed through cross-border capital inflows. Thus the monetary policy on one hand is constrained by interest rate management and on the other hand foreign capital inflows owing to their volatile nature present added dynamics to monetary policy operation. This leads to an "impossible trinity" problem, where the exchange rate stability is threatened as the central bank loses its ability to influence the same with its focus on the interest rate and free capital inflows.

The impossible trinity further presents two specific problems for central banks in emerging economies. On one hand, they put pressure on effective communication strategies of central banks in order to explain their stance of not having control on one of three variables: the 
exchange rate, financial integration, and interest rates. Such an explicit communication often articulated in terms of leaving the exchange rate to market forces, interest rates to fiscal policy situations and financial integration situations to global developments may therefore impact the "credibility bonus" central banks should enjoy in restoring confidence in financial markets. On the other hand, Aizenman et al. (2008) argue that emerging market economies are holding voluminous international reserves, which helped them to pursue both a higher level of exchange rate stability and a higher weighted average of the other two policy goals through active foreign exchange interventions. Obstfeld et al. (2008) argued that reserve accumulation, as a key tool for managing domestic financial instability, is used by central banks to protect the domestic banking sector, and domestic credit markets more broadly, while limiting external currency depreciation. Therefore, the contours of exchange rate management policy further extend to the manner in which reserve management strategies are to be pursued by central banks in emerging economies.

The Indian experience thus leaves us an insight that the the effectiveness of monetary policy in achieving macro-economic stability in emerging economies is constrained by exchange rate management policy pursued by central banks. Effectiveness of the central bank communication in currency-volatile situations and its ability to manage forex reserves on an ongoing basis will continue to influence monetary policy outcomes.

\section{d) Development of Appropriate Financial Institution Infrastructure is a Pre-condition for the Successful Pursuit of Monetary Policy}

As can be seen from the above conclusions, the successful operation of monetary policy depends in turn on the effectiveness of its regulatory policy, its exchange rate management policy, and the fiscal policy of government. However, the ability of these policies to influence the economy in turn depends upon their effective transmission, which in turn assumes a welldefined financial institution infrastructure is in place in the economy. In the absence of such infrastructure, the ability of monetary policy to influence the banking activity is constrained by factors such as inability of legal framework to address corporate/banking sector distress, and situations of inadequate liquidity arising on account of ineffectiveness of payment and settlement systems. Therefore in order to ensure that monetary policy is effectively implemented to achieve the desired outcome, regulatory reforms should focus on building a resilient financial institution infrastructure through robust credit information sharing arrangements (to identify 
early corporate distress and take remedial action), effective bankruptcy arrangements to protect the interests of bank lenders, and well-developed payment and settlement systems that provide desired liquidity into the system. The Indian experience outlines the steps being taken by the RBI toward the evolution of a new banking structure in the economy that is conducive towards effective implementation of monetary policy by the central bank.

\section{e) Multiple Policies Present Co-ordination Issues}

The Indian experience outlines the perspective that there are four components to macroeconomic stability - price stability, financial stability, fiscal stability, and exchange rate stability. Accordingly, macro-economic stability could be achieved through four specific public policies - monetary policy (for price stability), regulatory policy (for financial stability), fiscal policy (for fiscal stability), and exchange rate management policy (for exchange rate stability). However, all policies, other than monetary policies have multiple instruments that could result in multiple outcomes. However, the impact of these outcomes is generally seen on monetary policy, which has limited instruments (manipulation of interest rates and reserve money in the economy) at its disposal. Thus monetary policy independence in an emerging market economy is highly dependent upon the coordination between various individual policies (regulatory, fiscal and exchange rate management) and monetary policy.

Multiplicity of policies also often leads to confusion when policy makers choose to apply one policy instrument for a different policy objective. Three examples observed during 2013 can be cited based on the discussion in the previous sections of this paper. First, the application of a monetary policy instrument (raising short-term interest rates) by the RBI for exchange rate management, which has done collateral damage in terms of a rise in price of bonds with its financial impact on the banking system. Second, in order to contain the currency volatility, the RBI has to finally apply regulatory policy by issuing guidelines for a) restricting banks from importing gold and $b$ ) giving relaxations to reserve requirements on foreign currency deposits, thereby enabling bankers to pass on the benefit to depositors ${ }^{4}$ in the form of higher interest rates. Third, the application of a monetary policy tool (raising the interest rates) to contain inflation that is considered to be resulting from fiscal operations of the Government

\footnotetext{
${ }^{4}$ The extant the RBI regulations prescribe a ceiling on the interest rate to be offered to customers on non-resident deposits. The measures mentioned above sought to relax the position by providing relaxations to reserve requirements applicable for such deposits. The benefit that will accrue banks out of the relaxation could be passed on by banks as higher interest rate to customers.
} 
of India. Such inconsistent policy applications for varied objectives pose coordination problems in the policy-making sphere.

There have been studies in the existing academic literature that reviewed inter-linkages between monetary, fiscal and regulatory policies to a large extent, however only by taking two policies at a time (for instance, monetary policy and fiscal policy coordination, or monetary policy and regulatory policy coordination). However, new areas of research will emerge with a) the extension of this coordination problem to inter-se amongst all three policies and b) the inclusion of an exchange rate policy to this coordination exercise. The experience of the Indian economy during the last decade offers interesting insights and provides further empirical evidence in this direction. 


\section{Bibliography}

Aizenman, J. (2010). “The Impossible Trinity (aka The Policy Trilemma),” Santa Cruz Department of Economics, Working Paper Series qt9k29n6qn, Department of Economics, UC Santa Cruz.

Aizenman, J., Chinn, M.D., and Ito, H. (2008). "Assessing the Emerging Global Financial Architecture: Measuring the Trilemma's Configurations over Time." NBER Working Paper (No: 14533). National Bureau of Economic Research.

Allen, F. and Gale, D. (2007). "Understanding Financial Crises." Clarendon Lectures in Finance.

Prakash, A. (2012). "Major Episodes of Volatility in the Indian Foreign Exchange Market in the Last Two Decades (1993-2013): Central Bank's Response." RBI Occasional Papers Vol. 33. No. $1 \& 2$.

Sinha, A. (2011) Deputy Governor, Reserve Bank of India. "Macroprudential Policies: Indian Experience." Address at Eleventh Annual International Seminar on Policy Challenges for the Financial Sector on "Seeing both the Forest and the Trees - Supervising Systemic Risk" co-hosted by The Board of Governors of the Federal Reserve System, The International Monetary Fund, and The World Bank at Washington, D.C, June 1-3.

Bernanke, B. (2004). "The Great Moderation.” At the meetings of the Eastern Economic Association, Washington DC., on February 20.

Bezemer, D.J. (2009). "No One Saw This Coming: Understanding Financial Crisis through Accounting Models." Groningen: Faculty of Economics, University of Groningen.

Blinder, A.S. (1982). "Issues in the Coordination of Monetary and Fiscal Policy." NBER Working Papers 0982, National Bureau of Economic Research, Inc.

Borio, C. (2003): "Towards a Macro-prudential Framework for Financial Supervision and Regulation?" CESifo Economic Studies, Vol. 49, no 2/2003, Summer. 181-215

Cooper, G. (2005). "The Burden of Sisyphus (Preventing Deflation: Revisiting the Lessons from Japan's Experience in the 1990s)." Deutsche Bank Fixed Income Research Series. May.

(2010). "The Origin of Financial Crises: Central Banks, Credit Bubbles and the Efficient Market Fallacy.” Harriman House.

De Antoni, E. (2007). “Minsky’s Financial Instability Hypothesis: An Interpretation Based on Bounded Rationality." University of Trento.

Ferri, P. and Minsky, H.P. (1991). "Market Processes and Thwarting Systems." Levy Economics Institute Working Paper (No: 64). 
Friedman, M. and Schwartz, A.J. (1963). "A Monetary History of the United States, 18671960.” Princeton, N.J.: Princeton University Press.

Godley, W. and Lavoie, M. (2007). "Fiscal Policy in a Stock-Flow Consistent Model.” Journal of Post Keynesian Economics. 30(1):79-100

Government of India (2012). Report of the Working-Group on Estimation of Investment, its Composition and Trend for Twelfth Five-Year Plan (2012-13 to 2016-17). June

(2013). "Public Debt Management Report." Quarterly publications. Published by the Ministry of Finance.

Greenspan, A. (1997). "Rules vs. Discretionary Monetary Policy.” Remarks presented at the Center for Economic Policy Research, Stanford University. September.

Holmes, A.R. (1969). "Operational Constraints on the Stabilization of Money Supply Growth.” In F.E. Morris (ed.) "Controlling Monetary Aggregates.” Nantucket Island. MA: Federal Reserve Bank of Boston. 65-77.

IMF (2012). "Balancing Fiscal Policy Risks". World Economic and Financial Surveys. Fiscal Monitor International Monetary Fund. April.

Kaminsky, G.L. and Reinhart, C.M. (2000). “On Crises, Contagion and Confusion.” Journal of International Economics 51: 145-68.

Keen, S. (2011). “Debunking Economics: Naked Emperor Dethroned?” London: Zed books.

2013. "Predicting the 'Global Financial Crisis': Post-Keynesian Macroeconomics". Economic Record, Vol. 89, Issue 285, pp. 228-254, June.

Kelkar Committee (2012). "Road Map for Fiscal Conoslidation”. Constituted by Ministry of Finance. Government of India. September.

Kindleberger, C. and Aliber, R. (2005 [1978]). "Manias, Panics and Crashes: A History of Financial Crises." Fifth Edition. New Jersey: Wiley.

Kodres, L. and Pritsker, M. (1998). "A Rational Expectations Model of Financial Contagion." Board of Governors of the Federal Reserve System. Mimeo. October.

Kose, M.A., Otrok, C. and Prasad, E.S. (2012). "Global Business Cycles: Convergence Or Decoupling?" International Economic Review. Department of Economics. University of Pennsylvania and Osaka University Institute of Social and Economic Research Association. vol. 53(2), pages 511-538, 05.

Kregel, J. (2007). "The Natural Instability of Financial Markets," Working Paper No. 523, The Levy Economics Institute of Bard College, New York.

Krugman, P. and Eggertsson, G.B. (2012). "Debt, Deleveraging, and the Liquidity Trap: a Fisher-Minsky-Koo Approach.” Quarterly Journal of Economics, 127 (3): 1469-1513. 
Kydland, F.E. and Prescott, E.C. (1990). "Business Cycles: Real Facts and a Monetary Myth.” Federal Reserve Bank of Minneapolis Quarterly Review. 14(2). 3-18.

Minsky, H.P. (1984). “Can "IT” happen again: Essays on Instability and Finance.” M.E. Sharpe (2008 [1986]). “Stabilising the Unstable Economy.” Mc. Graw Hill.

Mohanty, D. (2010). "Monetary Policy Framework in India: Experience with MultipleIndicators Approach”. Speech by Shri Deepak Mohanty, Executive Director, Reserve Bank of India, delivered at the Conference of the Orissa Economic Association in Baripada, Orissa. February 21.

Moore, B.J. (1979). “The Endogenous Money Stock.” Journal of Post Keynesian Economics. 2 (1): 49-70.

Obstfeld, M., Shambaugh, J.C., and Taylor, A.M. (2008). "Financial Stability, The Trilemma, and International Reserves" NBER Working Paper 14217 (August).

Overtveldt, J. Van (2010) 'Bernanke's Test - Ben Bernanke, Alan Greenspan, and the Drama of the Central Banker" Chicago: A Gate Publishing.

Papadimitriou, D.B., and Wray, L.R. (2008). "Minsky's Stabilizing an Unstable Economy: Two Decades Later.” Introduction in Minsky 2008 [1986]. "Stabilizing an Unstable Economy." McGraw Hill.

Rajan, R. (2010). "Fault Lines: How Hidden Fractures still Threaten the World Economy". Harper Collins India.

2005. "Has Financial Development Made the World Riskier?" National Bureau of Economic Research Working Paper No. 11728. November.

RBI (Reserve Bank of India) (2009). Fiscal Monetary Co-ordination. Report on Currency and Finance (2009-12). Mumbai.

(2010). Global Financial Crisis and the Indian Economy. Report on Currency and Finance (2008-09). Mumbai. July.

(2013). Financial Stability Report. Mumbai. December.

(2014). Financial Stability Report. Mumbai. July

Reddy, Y.V. (2008). “India and Global Financial Crisis.” New Delhi: Orient Blackswan. (2011). “Global Crisis, Recession and Uneven Recovery.” New Delhi: Orient Blackswan. 
Roubini, N. (2010). "Crisis Economics—A Crash Course in the Future of Finance." Penguin Books Ltd.

Sargent, T.J. and Wallace, N. (1981). "Some Unpleasant Monetarist Arithmetic." Quarterly Review, Federal Reserve Bank of Minneapolis, 5 (Fall).

Tymoigne, E. (2009). “A Critical Assessment of Seven Reports on Financial Reform: A Minskyan Perspective - Treasury, CRMPG Reports, Financial Stability Forum." Working Paper No: 574. Levy Economic Institute of the Bard College.

Wolf, M. (2008). “Fixing Global Finance.” Baltimore: John Hopkins University Press, 2008

Wray, L.R. (2007). "Lessons from the Sub-prime Meltdown." Working Paper No. 522. The Levy Economics Institute of Bard College. New York. 